\title{
Meningkatkan pengetahuan orang tua dalam mendidik anak di era digital di Kecamatan Koto Gasib Kabupaten Siak Provinsi Riau
}

\author{
Ria Novianti, Febrialismanto ${ }^{\star}$, Enda Puspitasari, \& Hukmi \\ Fakultas Keguruan dan IImu Pendidikan, Universitas Riau, Indonesia \\ *febrialismanto@lecturer.unri.ac.id
}

\begin{abstract}
This community service activity aims to improve the knowledge of parents in educating children in the digital era. It is important to be done so that parents can respond to technological developments and adjust parenting for children, so technology which is essentially created for the ease and goodness of human life, will not give negative affect children and adolescents. Therefore, parents need to have adequate information and knowledge. Through this activity, we convey a variety of materials on how to educate children in the digital age with the hope that young children will be able to socialize, empathize, speak well, and be healthy, both physically and spiritually. The activities are divided into two parts, socialization, and training, while the participants of this activity are mothers in Koto Gasib District Siak Regency, which has young children. From the implementation of this community service, it can be concluded. There was an improvement in parent's knowledge. Pretest results were $47.61 \%$ and increased to $76.90 \%$ on posttest. This indicates that the community service activity went well and effectively.
\end{abstract}

\begin{abstract}
Abstrak Kegiatan pengabdian kepada masyarakat ini dilakukan dengan tujuan untuk meningkatkan pengetahuan orang tua dalam mendidik anak di era digital. Hal ini dirasakan penting untuk dilakukan agar orang tua bisa menyikapi perkembangan teknologi dengan baik dan menyesuaikan pola pengasuhan dengan perkembangan zaman, sehingga teknologi yang pada dasarnya diciptakan untuk kemudahan dan kebaikan hidup manusia, tidak malah memberi dampak negatif terutama pada anak-anak dan remaja. Untuk itu orang tua perlu memiliki informasi dan pengetahuan yang memadai. Melalui kegiatan ini disampaikan berbagai materi mengenai cara mendidik anak di era digital dengan harapan terwujudnya anak usia dini yang mampu bersosialisasi, berempati, berbahasa dengan baik, serta sehat jasmani dan rohani. Kegiatan dibagi pada dua bagian, yakni sosialisasi dan pelatihan, sedangkan yang menjadi peserta kegiatan ini adalah para ibu di Kecamatan Koto Gasib Kabupaten Siak yang memiliki anak usia dini. Dari pelaksanaan kegiatan pengabdian kepada masyarakat ini dapat disimpulkan bahwa terjadi peningkatan pengetahuan orang tua di mana sebelum mengikuti kegiatan hasil pretest adalah $47.61 \%$ lalu menjadi $76.90 \%$ pada posttest. Hal ini mengindikasikan bahwa kegiatan pengabdian kepada masyarakat berjalan dengan baik dan efektif.
\end{abstract}

Keywords: gadget; parenting; parents; education; phubbing

\section{ठ OPEN ACCESS}

Citation: Novianti, R., Febrialismanto., Puspitasari, E., \& Hukmi. (2020). Meningkatkan pengetahuan orang tua dalam mendidik anak di era digital di Kecamatan Koto Gasib Kabupaten Siak Provinsi Riau. Riau Journal of Empowerment, 3(3), 183-190. https://doi.org/10.31258/raje.3.3.183-190

Paper type: Community service

Received: 2020-03-22 Revised: 2020-09-11 Accepted: 2020-09-14

Language: Bahasa Indonesia (id)

ISSN 2623-1549 (online), 2654-4520 (print)

(c) 2020 Ria Novianti, Febrialismanto, Enda Puspitasari, \& Hukmi. Author(s) retain the copyright of article published in this journal, with first publication rights granted to Riau Journal of Empowerment. The article is licenced under Creative Commons Attribution 4.0 Internationa License. This license permits unrestricted use, distribution, and reproduction in any medium, provided the original author and source are credited. 


\section{PENDAHULUAN}

Anak-anak yang lahir pada era digital saat ini hidup di dunia di mana teknologi terintegrasikan dengan kehidupan sehari-hari. Para orang tua menggunakan teknologi dalam bekerja, berhubungan sosial dan melakukan berbagai kegiatan di rumah. Semua bisa dilakukan dengan lebih efektif dan efisien dari segi waktu, tenaga maupun biaya. Menurut Chapman dan Pellicane (2014), penggunaan teknologi dalam bentuk gawai pada anak-anak dirasakan orang tua dapat memberikan nilai positif terutama pada perkembangan anak dan kemampuan literasi. Bahkan sebagian besar orang tua berpendapat bahwa penggunaan teknologi membantu anak memiliki kesiapan untuk bersekolah dan berpengaruh pada kesuksesan di bidang akademis. Namun agar anak bisa memperoleh sisi positif perkembangan teknologi, tentunya harus ada hal-hal yang diperhatikan pada pengasuhan yang diterapkan dalam keluarga.

"Didiklah anakmu sesuai zamannya, karena mereka hidup bukan di zamanmu". Demikian ungkapan Sayyidina Ali Bin Abi Thalib mengenai pengasuhan anak. Bila dicermati, kalimat ini sangatlah tepat menggambarkan peran dan tugas orang tua di era milenial yang memiliki tantangan yang berbeda dari para orang tua sebelumnya. Perbedaan tersebut terutama disebabkan oleh perkembangan teknologi digital yang sangat pesat dan mempengaruhi semua kalangan usia, termasuk anak-anak, sehingga pola pengasuhan orang tua pada anak pun harus menyesuaikan dengan perubahan zaman. Mitchell (2013) menyatakan bahwa parenting di zaman sekarang sulit untuk didefinisikan karena selalu saja ada gaya pengasuhan baru yang ditambahkan. Kini orang tua sangat banyak memperoleh saran, baik dari psikolog anak hingga para blogger di Internet yang merekomendasikan praktik pengasuhan yang mereka anggap terbaik.

Anak usia dini yang berada pada rentang usia 0-6 tahun mengalami pada proses pertumbuhan dan perkembangan yang fundamental. Pola pertumbuhan dan perkembangan anak pada masa ini mempengaruhi kondisi fisik dan mentalnya ketika dewasa nanti. Sedemikian pentingnya masa usia dini ini sehingga disebut pula dengan masa emas atau golden age (Yunika et al., 2019). Kesalahan pengasuhan orang tua akan membekas pada diri anak, termasuk penggunaan teknologi yang berlebihan pada usia ini. Selain itu kebiasaan orang tua yang dapat diamati anak, termasuk dalam menggunakan gawai sehari-hari akan ditiru oleh anak. Orang tua yang tidak bisa lepas dari gawai akan kesulitan menerapkan disiplin menggunakan gawai bagi anak. Sebagaimana yang disampaikan oleh Sulaiman dan AlMuscati (2017), bahwa berdasarkan penelitian, generasi milenial memiliki kesamaan dengan orang tua mereka dalam nilai-nilai budaya dan bekerja.

Teknologi saat ini telah menjadi bagian tak terpisahkan dan sangat membantu kehidupan kita sehari-hari. Mulai dari komunikasi, belajar, bisnis, hingga olahraga dan rekreasi dapat dilakukan dengan teknologi. Salah satu media teknologi yang paling umum digunakan adalah gawai. Saat ini sembilan dari sepuluh anak sudah menggunakan gawai. Bahkan mereka sudah akrab dengan media ini sebelum mereka bisa berjalan dan berbicara. Cukup sering kita lihat di sekeliling, anak-anak usia dini yang menggunakan gawai saat orang tua mereka sedang berbelanja, bekerja, mengikuti kegiatan, berbincang-bincang atau melakukan aktivitas lain dengan tujuan agar anak tidak rewel dan asyik dengan gawainya. Lalu bila gawai itu diambil maka anak akan marah bahkan mengamuk.

Meskipun gawai memudahkan kehidupan manusia, namun penggunaan gawai pada anak terlalu dini, tanpa aturan dan pengawasan yang tepat maka akan membawa masalah, salah satunya adalah kecanduan gadget. Menurut Setianingsih et al. (2018) kecanduan gawai dapat 
mempengaruhi perkembangan otak anak karena produksi hormon dopamine yang berlebihan mengganggu kematangan fungsi prefrontal korteks yang bertugas mengendalikan emosi, kemampuan mengontrol diri, bertanggung jawab, mengambil keputusan, dan nilai moral lainnya. Selain itu kecanduan gawai dapat mengakibatkan anak mengalami kesulitan berkonsentrasi dan memunculkan perilaku hiperaktif. Lebih lanjut, Paturel (2014) menyatakan bahwa sebuah studi yang diadakan oleh peneliti di China dengan menggunakan magnetic resonance imaging (MRI) terhadap 18 orang mahasiswa yang bermain video game selama rata-rata 10 jam per hari dan sebagian besar memainkan game yang mengandung konten kekerasan, World of Warcraft, ternyata memperlihatkan perbedaan dibandingkan dengan grup kontrol yang terdiri dari para mahasiswa yang hanya bermain game dengan waktu rata-rata dua jam per hari, di mana para pecandu game ini memiliki lebih sedikit wilayah abu-abu di otak (bagian otak untuk berpikir).

Laini et al. (2018) menyatakan bahwa anak yang memiliki durasi penggunaan gawai yang tinggi tanpa keterlibatan orang tua akan memiliki perilaku pro sosial yang lebih rendah dibandingkan anak lain yang menggunakan gawai di bawah bimbingan orang tua. Menurut Novianti (2018), penggunaan gawai pada anak berkaitan erat dengan peran orang tua. Saat ini bisa dengan mudah kita temui sekelompok orang yang duduk bersama tapi sibuk dengan gawainya masing-masing, bisa saat mereka sedang menunggu makanan di restoran atau saat bersama-sama di sebuah ruangan. Kondisi ini dikenal dengan istilah phone snubbing atau disingkat phubbing, yakni tidak mengindahkan orang lain di dalam sebuah lingkungan karena lebih fokus pada gawai dari pada berinteraksi dan berkomunikasi secara langsung. Selanjutnya Novianti et al. (2019), menyatakan bahwa masih ada sebagian orang tua yang tidak memberi aturan bagi anak dalam menggunakan gawai. Jumlah ini akan meningkat bila orang tua tidak mendapat informasi mengenai dampak negatif penggunaan gawai secara berlebihan bagi anak. Karenanya orang tua perlu waspada dan menerapkan aturan yang jelas bagi anak untuk menghindari munculnya permasalahan-permasalahan pada perkembangan anak. Oleh karena, maka perlu dilakukan kegiatan Sosialisasi Pendidikan Anak di Era Digital bagi orang tua di Kecamatan Koto Gasib, Kabupaten Siak Provinsi Riau.

\section{METODE PENERAPAN}

Kegiatan pengabdian kepada masyarakat yang dilaksanakan di Kecamatan Koto Gasib Kabupaten Siak Provinsi Riau ini menggunakan metode participatory rural appraisal yang merupakan suatu upaya untuk membimbing masyarakat lokal agar dapat menganalisis kondisi mereka sendiri dan untuk merencanakan dan mengambil tindakan dalam mengatasi permasalahan yang dihadapi (Cavestro, 2003).

Tahap pertama yang dilakukan adalah sosialisasi mengenai pendidikan anak di era digital pada peserta yang terdiri dari para ibu di Kecamatan Kota Gasib. Berbagai materi mengenai berkaitan dengan penggunaan gawai pada anak disampaikan secara sistematis untuk membuka wawasan peserta. Lalu kegiatan dilanjutkan dengan tahap kedua yakni pelatihan di mana peserta akan mendiskusikan dan menyusun rencana tindak lanjut berdasarkan permasalahan yang mereka hadapi dalam mendidik anak dan apa yang mereka harapkan dapat dicapai dengan menyesuaikan pola asuh dengan perkembangan teknologi.

Berikutnya, untuk menilai ketercapaian tujuan kegiatan pengabdian kepada masyarakat ini, maka dilakukan evaluasi dengan pemberian tes sebelum dan sesudah dilaksanakannya kegiatan (pretest-postest). Metode evaluasi ini dipilih untuk melihat peningkatan pemahaman 
peserta dari sebelum memperoleh informasi mengenai pendidikan anak di era digital pada tahap sosialisasi dan mendiskusikan rencana tindak lanjut pada tahap pelatihan hingga setelah kedua tahapan kegiatan tersebut selesai dilaksanakan. Tahap ini dimulai dengan (1) merancang soal pretest dan posttest untuk mengukur tingkat pemahaman peserta terhadap materi yang disampaikan. Materi tes terdiri dari dua puluh soal pilihan ganda yang seluruhnya terkait dengan materi yang disampaikan. (2) Peserta diminta mengerjakan pretest sehingga diperoleh gambaran pengetahuan awal mereka terhadap pendidikan anak di era digital, (3) peserta kembali diminta mengerjakan posttest pada akhir kegiatan. Kemudian (4) dilakukan skoring untuk memperoleh nilai pretest dan posttest peserta, lalu dihitung persentase peningkatannya untuk mengetahui efektivitas pelaksanaan kegiatan.

\section{HASIL DAN KETERCAPAIAN SASARAN}

\section{Sosialisasi}

Tahap sosialisasi diawali dengan penyusunan materi sosialisasi pendidikan anak di era digital yang mencakup pengertian dan jenis-jenis gawai, karakteristik anak generasi alpha, manfaat gawai bagi anak, aturan dalam memberikan gawai pada anak, serta dampak positif dan negatif gawai bagi anak. Materi-materi ini dipilih dengan tujuan agar para peserta memahami materi pendidikan anak di era digital secara menyeluruh sehingga pada akhir kegiatan dapat menyusun rencana tindak lanjut yang akan diterapkan dalam pendidikan anak di dalam keluarga.

Peserta yang terdiri dari para ibu di Kecamatan Kota Gasib Kabupaten Siak, berkumpul di TK Kasih Ibu di mana kegiatan Pengabdian kepada Masyarakat ini diadakan. Selama penyampaian materi, para ibu terlihat antusias dan mengajukan berbagai pertanyaan berdasarkan apa yang mereka alami dalam mengasuh dan mendidik anak-anaknya di rumah. Para orang tua semula hanya berpikir bahwa penggunaan gawai yang berlebihan itu adalah gejala wajar dan tidak akan memiliki dampak negatif yang berarti bagi perkembangan anak. Hal inilah yang menjadi pemicu bagi orang tua untuk menanyakan secara kritis, karena ternyata yang ideal dari konsep yang disampaikan pengabdi cukup berbeda dengan empirik yang mereka alami. Tentunya dengan dialog serta bukti referensi yang disampaikan cukup membuat peserta mengerti dan menerima apa yang disampaikan oleh pengabdi. Salah satunya adalah mengenai penerapan pola asuh yang tepat dalam keluarga sebagaimana yang dinyatakan oleh Novianti dan Maria (2020) bahwa terdapat beberapa pola asuh dalam keluarga. Bila orang tua menerapkan pola asuh permisif maka orang tua memberikan kasih sayang namun tidak memberi batasan serta membiarkan anak melakukan semua hal yang disukainya. Orang tua biasanya sangat toleran, lembut dan tidak menuntut anak untuk berperilaku matang, mandiri dan bertanggung jawab. Kelak, anak akan memiliki kontrol diri yang rendah dan menjadi pribadi yang penuntut. Dalam hubungannya dengan penggunaan gawai, orang tua dengan pola asuh permisif ini akan membiarkan anak menggunakan gawai tanpa aturan sehingga anak kelak tidak mampu mengontrol dirinya dan terjerumus pada kecanduan gawai. Dalam sosialisasi ini disampaikan pula materi yang sejalan dengan pendapat Wong et al. (2019) bahwa orang tua yang memiliki pengetahuan mengenai internet yang baik, menerapkan pola asuh autoritatif, lebih terlibat dalam kegiatan online anak dan memiliki sikap positif terhadap internet, menjadi faktor-faktor yang berhubungan dengan kenyamanan orang tua dalam menjalankan supervisi penggunaan internet anak. 
Selain itu pemaparan materi yang disertai dengan berbagai tayangan gambar dan video dapat membuat mereka memahami materi dan menjadi lebih sadar mengenai pentingnya peran orang tua dalam mendampingi anak menggunakan gawai dan menerapkan aturan agar dampak negatif dapat dihindarkan. Pada akhirnya orang tua diharapkan mampu menyikapi penggunaan

Novianti et al. 187 gawai pada anak seperti yang disampaikan oleh Frahasini et al. (2018), bahwa orang tua perlu mengawasi situs yang dibuka dan digunakan oleh anak dengan memeriksa konten pada gawai yang anak. Sebagai tambahan, yang paling perlu diawasi adalah waktu penggunaan gawai dengan membatasi penggunaan gawai terutama di malam hari. Adapun jalannya sosialisasi dapat dilihat pada Gambar 1.

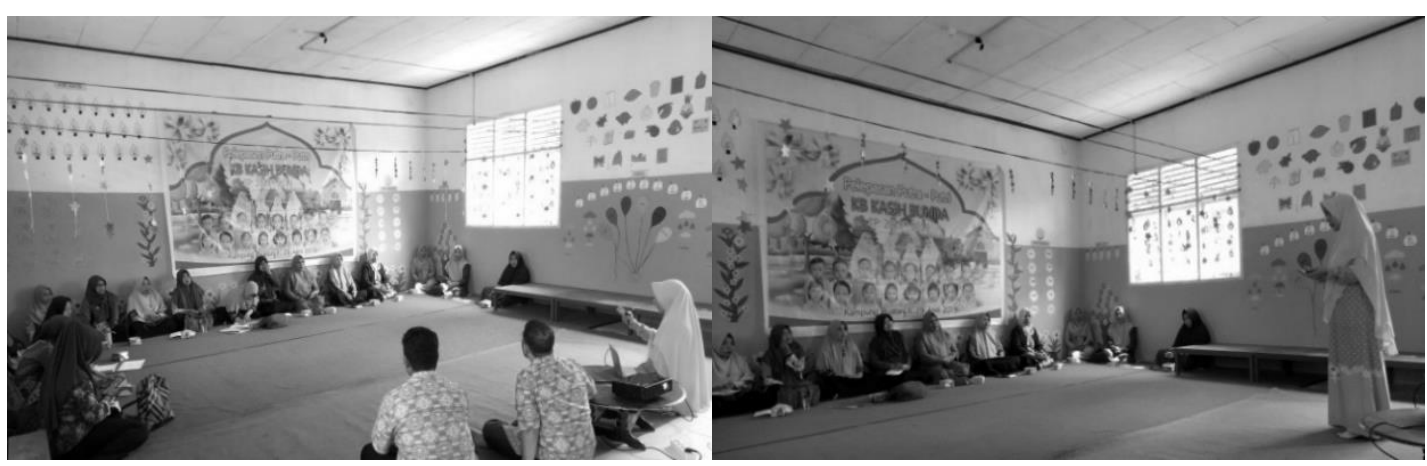

Gambar 1. Sosialisasi Pendidikan Anak di Era Digital

Selain antusiasme yang terlihat dalam proses pelaksanaan kegiatan sosialisasi, juga terlihat secara kuantitatif pengaruh dari program terhadap pelaksanaan kegiatan ini terhadap peserta, yang semula pretest berada pada $47.61 \%$ lalu menjadi $76.90 \%$ pada posttest sehingga terlihat peningkatan pemahaman peserta terhadap materi yang cukup signifikan.

\section{Pelatihan}

Setelah mendapatkan materi mendidik anak di era digital pada tahap sosialisasi, maka orang tua dibagi menjadi lima kelompok yang masing-masing terdiri dari empat peserta sehingga dapat saling berdiskusi dan mengerjakan tugas yang berkaitan dengan pendidikan anak di era digital. Sunita dan Mayasari (2018) menyatakan bahwa orang tua perlu mengajak anak bermain di luar rumah karena aktivitas ini dapat mempercepat tumbuh kembang anak. Selain itu orang tua juga dapat melibatkan anak dalam berbagai aktivitas harian seperti memasak agar dapat mempelajari keterampilan hidup. Dengan demikian perhatian anak tidak hanya tertuju pada gawai. Sahriana (2019) berpendapat orang tua perlu bersikap tegas atau membatasi anaknya yang berumur di bawah 12 tahun dalam menggunakan gawai, karena anak akan memperoleh dampak karena penggunaan gawai tersebut.

Berdasarkan informasi yang telah diperoleh, peserta menyusun rencana tindak lanjut berupa aturan penggunaan gadget bagi anak. Tiap kelompok memiliki rencana yang sama pada penyusunan jadwal penggunaan gawai bagi anak. Semua kelompok sepakat untuk tidak memberikan gawai pada anak berusia di bawah dua tahun dan membatasi waktu penggunaan gawai (screen time) sesuai usia anak, tentunya semakin mudah usia anak, semakin singkat waktu penggunaan gawai yang dibutuhkan. Selain itu konten tontonan dan aplikasi yang diperbolehkan adalah yang mengandung unsur edukasi seperti animasi edukasi islami, pengenalan kosa kata dan dasar-dasar literasi. Bahkan ada dua kelompok yang menyusun rencana untuk mengganti penggunaan media sosial YouTube dengan YouTube Kids sehingga orang tua dapat mengatur tontonan anak sesuai usianya. Perencanaan yang dibuat oleh peserta 
ini memperlihatkan pemahaman yang baik mengenai pengasuhan anak di era digital, bahwa gawai tentunya sudah menjadi kebutuhan keluarga namun perlu diarahkan hingga pemanfaatannya mendorong pertumbuhan dan perkembangan anak secara positif.

Setelah membuat aturan mengenai pembatasan screen time, maka peserta selanjutnya merencanakan untuk mendorong anak agar berkomunikasi dan berinteraksi secara aktif dengan orang lain, serta merancang permainan dan kegiatan sederhana yang dapat dilakukan anak sebagai pengganti kegiatan bermain menggunakan gawai. Hal yang menggembirakan, salah satunya adalah, karena beberapa peserta berasal dari wilayah tempat tinggal yang sama, mereka bersepakat untuk mengajak anak-anak mereka untuk keluar rumah pada waktu setelah Ashar atau jam 16.00 agar bisa bermain bersama dengan teman-teman seusianya. Peserta lalu merencanakan beberapa permainan tradisional yang dapat dilakukan anak secara berpasangan atau berkelompok seperti bola bekel, congklak, kelereng, gobak sodor dan lainnya. Tentunya ini merupakan hal yang sangat baik, bila selama ini anak lebih banyak bermain di dalam rumah dan tidak bisa bermain bersama dengan anak lain karena tidak ada anak-anak yang bermain di luar rumah, maka dengan kesepakatan yang dibuat oleh orang tua mereka, maka anak akan memiliki didorong untuk melakukan kegiatan yang tanpa mereka sadari dapat merangsang pertumbuhan dan perkembangan melalui bermain yang menyenangkan. Kemampuan berbahasa dan berkomunikasi yang selama ini hanya berlangsung satu arah ketika menggunakan gawai, kini berlangsung dua arah ketika bermain dengan teman. Anak juga belajar menahan diri, berempati dan menerima pendapat orang lain, serta mengelola emosinya. Tidak hanya itu, tiap permainan juga mendorong anak untuk bisa menyusun strategi, memecahkan masalah dan mengambil keputusan. Pada permainan yang bersifat fisik, maka kemampuan motorik anak akan terstimulasi. Berlari, menghindar, melompat dan memanjat akan membuat tubuh anak kuat, sehat dan terhindar dari risiko obesitas yang telah menjadi ancaman bagi generasi milenial saat ini.

Kegiatan pembuatan rencana tindak lanjut secara berkelompok ini pada akhirnya bukan hanya dapat diterapkan bagi anak-anak dari para ibu yang menjadi peserta pelatihan, tapi lebih luas lagi membawa manfaat bagi anak-anak yang ada di lingkungan tempat tinggal mereka melalui kesepakatan dan rencana yang dibuat oleh para peserta untuk mengurangi screen time dan mendorong anak untuk bermain bersama. Pelaksanaan kegiatan diskusi dan penugasan dapat dilihat pada Gambar 2.

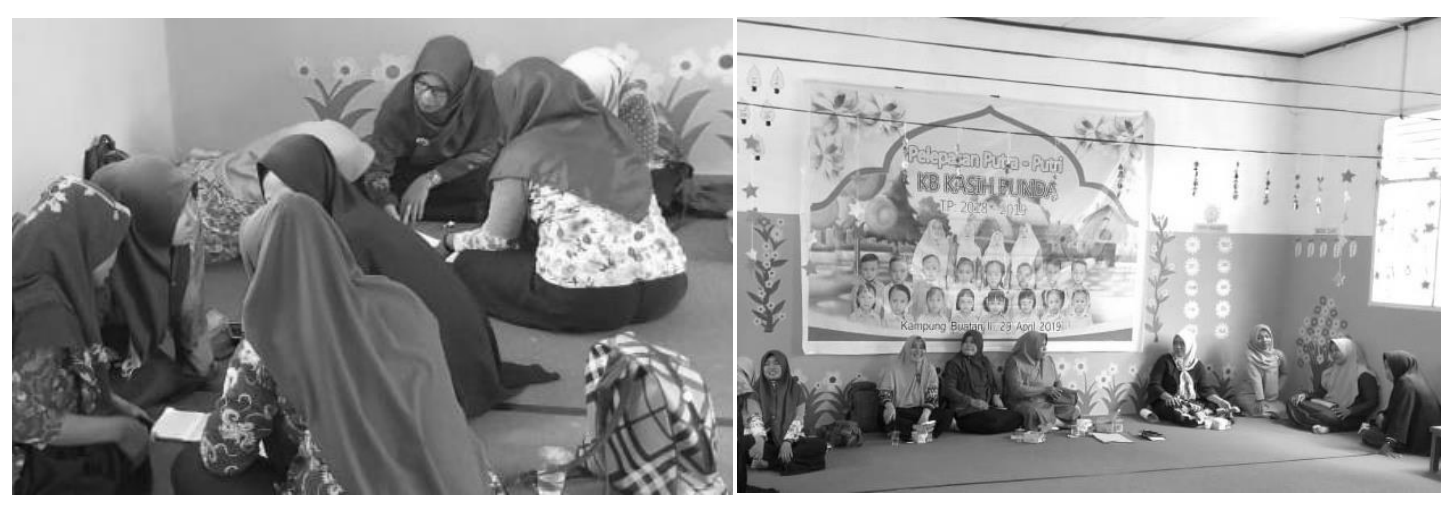

Gambar 2. Peserta Berdiskusi dan Mengerjakan Tugas dalam Pelatihan 


\section{KESIMPULAN}

Novianti et

Pelaksanaan kegiatan pengabdian kepada masyarakat yang dilakukan dalam bentuk sosialisasi bertajuk Pendidikan Anak Di era Digital Bagi Orang Tua di Kecamatan Koto Gasib Kabupaten Siak berjalan dengan baik dan sesuai rencana. Tujuan kegiatan pun tercapai dengan adanya al. peningkatan yang signifikan dari nilai pretest ke nilai posttest. Selain itu pelatihan di mana peserta dapat saling berdiskusi sambal mengerjakan penyusunan aturan penggunaan gawai, daftar kegiatan anak sehari-hari dan berbagai kegiatan bermain anak diikuti dengan antusias oleh peserta.

Kegiatan yang diikuti oleh para ibu yang memiliki anak usia dini ini diharapkan dapat memberi pemahaman bahwa teknologi selayaknya membawa keluarga semakin dekat satu sama lain, bukan malah menjauhkannya. Sehingga orang tua harus memainkan perannya secara bijak agar anak memiliki masa depan yang gemilang dan menciptakan hubungan yang hangat dan penuh kasih sayang dalam keluarga.

\section{Daftar Pustaka}

1. Cavestro, L. (2003). P.R.A. - Participatory Rural Appraisal Concepts Methodologies and Techniques. Universita' Degli Studi Di Padova.

2. Chapman, G., \& Pellicane, A. (2014). Growing up social: Raising relational kids in a screendriven world. Northfield Publishers.

3. Frahasini, Astuti, T.M.P., \& Atmaja, H.T. (2018). The Impact of The Use of Gadgets in School of School Age Towards Children's Social Behavior in Semata Village. Journal of Educational Social Studies, 7(2), 161-168. https://journal.unnes.ac.id/sju/index.php/jess/article/view/26842

4. Laini, A., Fridani, L., \& Hartati, S. (2018). Influence of Gadget Usage and Parent Involvement To Children'S Prosocial Behavior. Jurnal Imiah Pendidikan dan Pembelajaran, 2(2), 174-179. https://doi.org/10.23887/jipp.v2i2.15366

5. Mitchell, A. (2013, August). The Rise of the Millennial Workforce. Wired. https://www.wired.com/insights/2013/08/the-rise-of-the-millennial-workforce/

6. Novianti, R. (2018). PARENT-INK: Stiletto Book. Stiletto Book.

7. Novianti, R., \& Maria, I. (2020). Pendidikan Keorangtuaan. Ellunar.

8. Novianti, R., Hukmi, \& Maria, I. (2019). The role of parents in assisting the use of gadget in alpha generation [Conference presentation]. Joint International Conference: Seminar Serantau ke-9 and 3rd Universitas Riau International Conference on Educational Sciences. https://ices.prosiding.unri.ac.id/index.php/ICES/article/view/7900

9. Paturel, A. (2014). Game Theory: How do video games affect the developing brains of children and teens? Neurology Now, 10(3), 32-36.

10. Sahriana, N. (2019). Pentingnya Peran Orang Tua dalam Penggunaan Gadget pada Anak Usia Dini. Jurnal Smart Paud, 2(1), 60-66. https://doi.org/10.36709/jspaud.v2i1.5922

11. Setianingsih, S., Ardini, A.W., \& Khayati, F.N. (2018). Dampak Penggunaan Gadget pada Anak Usia Prasekolah Dapat Meningkatan Resiko Gangguan Pemusatan Perhatian dan Hiperaktivitas. Gaster, 16(2), 191. https://doi.org/10.30787/gaster.v16i2.297

12. Sulaiman, S.M.A., \& Al-Muscati, S.R.A. (2017). Millennial Generations \& Their Parents: Similarities and Differences. International Journal of Psychological Studies, 9(1), 121. https://doi.org/10.5539/ijps.v9n1p121

13. Sunita, I., \& Mayasari, E. (2018). Pengawasan Orangtua Terhadap Dampak. Jurnal Endurance, 3(3), 510-514. http://doi.org/10.22216/jen.v3i3.2485 
14. Wong, Y.C., Ho, K.M., \& Chen, H. (2019). Internet Supervision and Parenting in the Digital Age: The Case of Shanghai. The Open Family Studies Journal, 7(1), 112-123. https://doi.org/10.2174/18749224015070100112

15. Yunika, N., Novianti, R., \& Zulkifli, N. (2019). Hubungan Konsep Diri dengan Perilaku Moral Anak Usia Dini. Aulad: Journal on Early Childhood, 2(3), 73-80.

https://doi.org/10.31004/aulad.v2i3.36 